\title{
Intravascular large B-cell lymphoma with brain and bilateral lung involvement
}

\author{
Ceylan Altintas Taslicay ำ , ' Sevtap Dogan, ${ }^{1}$ Gozde Daglioz Gorur ${ }^{2}$
}

${ }^{1}$ Radiology, Kocaeli University School of Medicine, Izmit, Kocaeli, Turkey

${ }^{2}$ Nuclear Medicine, Kocaeli University School of Medicine, Izmit, Kocaeli, Turkey

\section{Correspondence to} Dr Ceylan Altintas Taslicay; ceylan_altintas@hotmail.com

Accepted 9 January 2022

\section{DESCRIPTION}

A 41-year-old man was referred to our hospital with a 2-month history of recurrent fever, sweating, cough and weight loss despite antibiotherapy treatment. At the time of admission, laboratory examinations revealed significant thrombocytopaenia and elevated levels of lactate dehydrogenase. Various bacterial cultures were negative. CT revealed normal findings of the bilateral lungs (figure 1A) and massive splenomegaly (figure 1C). A following examination using 18F-fluorodeoxyglucose (FDG) positron emission tomography (PET) CT showed diffuse high uptake in the spleen (figure 1D), and the bilateral lungs (figure 1B). Because of significant thrombocytopaenia and massive splenomegaly, diagnostic splenectomy was performed. Spleen specimen was examined pathologically, and intravascular large B-cell lymphoma (IVLBCL) was diagnosed. Pretreatment cranial MRI was performed due to the development of confusion in the patient. MRI showed abnormal signal areas in the pons on T2-weighted axial image (T2-WI) (figure 1E) and right frontal lobe
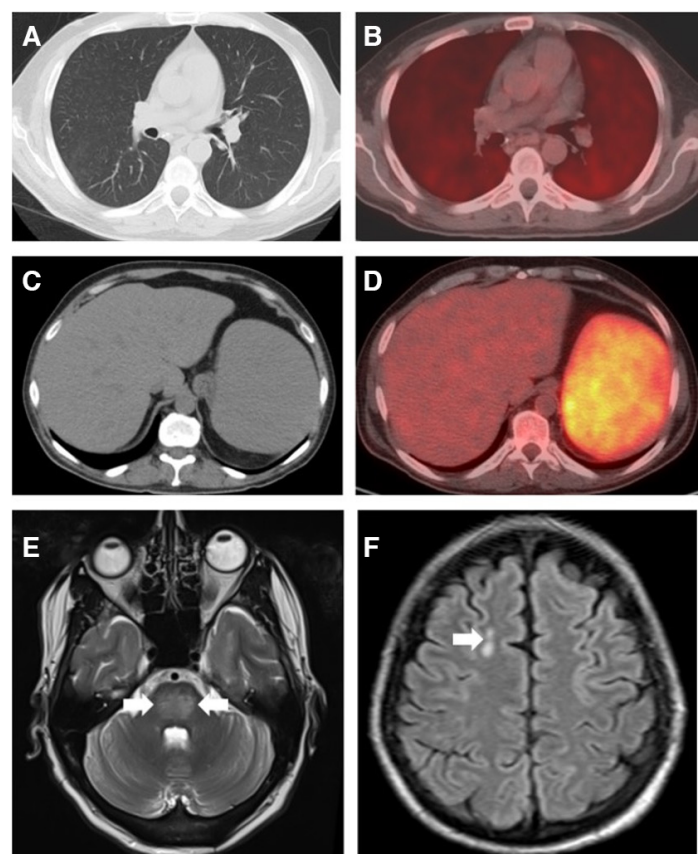

Figure $1(\mathrm{~A}-\mathrm{F})$ Images of the patient at presentation: $C T$ revealed normal findings of the bilateral lungs $(A)$ and massive splenomegaly (C). Positron emission tomography showed diffuse FDG uptake in the spleen (D), and the bilateral lungs (B). Cranial MRI showed abnormal signal areas in the pons on T2-weighted axial image ( $E$, white arrows) and right frontal lobe on FLAIR axial image ( $F_{\text {, }}$ white arrow). FDG, 18F-fluorodeoxyglucose. FLAIR, Fluidattenuated inversion recovery.
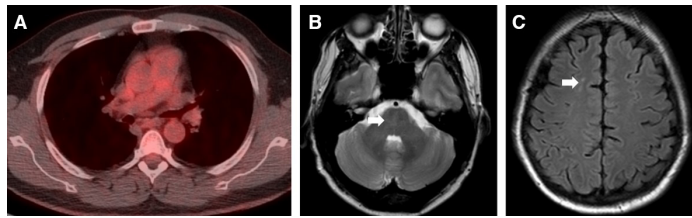

Figure 2 (A-C) Post-treatment control images: positron emission tomography showed disappearance of FDG uptake in the bilateral lungs (A). Cranial MRI showed disappearance of the lesion in the pons on T2-weighted axial image $(B$, white arrow) and regression of the lesions in the right frontale lobe on FLAIR axial image ( $C$, white arrow). FDG, 18F-fluorodeoxyglucose. FLAIR, Fluidattenuated inversion recovery.

on FLAIR axial image (figure 1F). These findings were suspicious for IVLBCL involvement. After treatment, complete remission (CR) was confirmed with PET CT and cranial MRI. PET CT demonstrated disappearance of FDG uptake in the bilateral lungs (figure 2A). Cranial MRI showed disappearance of the lesion in the pons (figure 2B) and regression of the lesions in the right frontale lobe (figure 2C). PET CT and cranial MRI which performed 17 months later confirmed that CR had been maintained.

IVLBCL is an aggressive lymphoma with poor prognosis due to variable and nonspecific symptoms and delays in diagnosis. ${ }^{1}$ The most common symptoms are fever, weight loss and sweating. ${ }^{1}$ IVLBCL showes a pulmonary FDG uptake even in the absence of CT abnormalities. ${ }^{2}$ Also, most patients with IVLBCL present abnormal findings on pretreatment cranial MRI even in the absence of neurological symptom. ${ }^{3}$ These findings are infarct like lesions, non-specific white matter lesions, meningeal enhancement, masslike lesions and hyperintense lesions in the pons on T2WI. ${ }^{4}$ Especially, hyperintense lesion in the pons on

Learning points

- Intravascular large B-cell lymphoma (IVLBCL) is an aggressive lymphoma with poor prognosis due to non-specific symptoms and delays in diagnosis.

- IVLBCL should be included in the differential diagnosis of the patient with unexplained fever and weight loss if the patient has abnormal signal areas in the pons on T2-weighted axial image, and/or diffusely increased pulmonary 18F-fluorodeoxyglucose uptake on positron emission tomography without corresponding CT abnormality. 
Images in...

T2WI is frequently observed. It is relatively specific to IVLBCL and this pattern may be precious for diagnosis.

Contributors CAT, SD and GDG evaluated the patient's initial and post-treatment control images and contributed to the diagnosis. All authors wrote the manuscript and approved it for publication.

Funding The authors have not declared a specific grant for this research from any funding agency in the public, commercial or not-for-profit sectors.

Competing interests None declared.

Patient consent for publication Consent obtained directly from patient(s)

Provenance and peer review Not commissioned; externally peer reviewed.

Case reports provide a valuable learning resource for the scientific community and can indicate areas of interest for future research. They should not be used in isolation to guide treatment choices or public health policy.

\section{ORCID iD}

Ceylan Altintas Taslicay http://orcid.org/0000-0003-4459-4114

Copyright 2022 BMJ Publishing Group. All rights reserved. For permission to reuse any of this content visit https://www.bmj.com/company/products-services/rights-and-licensing/permissions/

BMJ Case Report Fellows may re-use this article for personal use and teaching without any further permission.

Become a Fellow of BMJ Case Reports today and you can:

- Submit as many cases as you like

- Enjoy fast sympathetic peer review and rapid publication of accepted articles

- Access all the published articles

- Re-use any of the published material for personal use and teaching without further permission

\section{Customer Service}

If you have any further queries about your subscription, please contact our customer services team on +44 (0) 2071111105 or via email at support@bmj.com.

Visit casereports.bmj.com for more articles like this and to become a Fellow 